\title{
Dativus Ethicus in the Balkan Languages
}

\author{
Ekaterina Tarpomanova \\ Institute for Bulgarian Language, Bulgarian Academy of Sciences \\ katja@dcl.bas.bg
}

\begin{abstract}
The paper presents a contrastive study of the ethic dative case of the personal pronouns in the languages of the Balkan Sprachbund outlining the similarities between them, but also discussing peculiarities of each language. It aims at analyzing the functioning and the meaning of different pronominal forms in dativus ethicus ( $1^{\text {st }}$ person singular or plural, $2^{\text {nd }}$ person, $1^{\text {st }}+2^{\text {nd }}$ person of the personal pronouns, reflexive pronoun) found in authentic examples in order to indicate that dativus ethicus is one of the common features of the pronominal systems of the Balkan languages.
\end{abstract}

\section{Introduction}

The common features of the languages of the Balkan Sprachbund (Bulgarian, Greek, Albanian and Romanian) have been widely discussed in the linguistic literature. Since the first generalizing work on Balkan linguistics of the danish linguist Kristian Sandfeld (1930) was published, a number of authors have analyzed linguistic phenomena at all the language levels shared by the Balkan languages, such as unification processes of the phonological systems, development of analytic noun systems, syncretism of genitive and dative, future tense formation, lack of infinitive, postposition of the definite article, clitic doubling, etc. Despite some critics that Balkan linguistics has already exhausted its research field or that there is a danger to "break the structural-typological matrix" of a language if it's only seen as being a part of a Sprachbund (as in Reiter 1994), the interest toward Balkan linguistic peculiarities doesn't seem to have decreased. Furthermore, a number of monographs on Balkan linguistics appeared only in the last 20 years, analyzing and systematizing the common features of the Balkan languages (Steinke \& Vraciu 1999, Asenova 2002, Demiraj 2004, Feuillet 2012, among others).

Traditionally the focal point of research in Balkan linguistics are the common morpho-syntactic phenomena of the Balkan languages. Pronominal systems

\section{(cc) BY-NC-ND}


haven't been a center of interest, although they show multiple similarities. This paper presents a synchronic contrastive study of a function of the pronouns' dative case called dativus ethicus in the modern Balkan languages. It aims at studying the usage of the ethic dative in all the forms found in the Balkan languages on the basis of authentic examples extracted from fiction and internet. The paper will show that dativus ethicus is not only preserved in those languages, but also has a high frequency and identical usages in colloquial speech.

\section{Dativus Ethicus in Indo-European Languages}

Dativus ethicus is a function of the personal pronouns in dative with an ancient origin in the Indo-European languages. Forms of the ethic dative are encountered in Old Greek and Latin, indicating that the person in dative has a special interest towards the person or the thing spoken (Schwyzer 1950). It is alive in many of the present-day Indo-European languages: in French - Prends-moi le bon parti. 'You should do the right thing.'; Regarde-moi ça! 'Look at this!'; in English the construction with the preposition on + a personal pronoun in any person and number is encountered - They've gone and bought that bike on us/ on you/ on me/ on him/ on them.; in Dutch - Wat doe je me daar nou? 'What's going on with you now?', Waar kom je me nou mee aanzelten? 'What are you going to do now?'; in German - Comm du mir bloss nachhause. 'Just come into my house.' (DuFeu 1998). The ethic dative is also found in some of the Slavic languages (mainly West and South Slavic) - Czech, Polish, Slovak, Serbo-Croatian, Bulgarian, and in the languages of the Balkan Sprachbund - Bulgarian, Greek, Romanian and Albanian. It occurs with different frequency and distribution in different languages, for instance in French, although quite current, it is restricted to the $1^{\text {st }}$ person only, especially after a verb in imperative. Fischer (1997:79) mentions that the ethic dative causes some particular problems in German-to-English translation, not having a direct counterpart in English. In this inhomogeneous situation, the Balkan languages manifest impressive similarities which can be considered to be due to the convergence processes in their development.

\section{Dativus Ethicus in the Balkan Folklore}

A thorough analysis of the origin and functions of dativus ethicus in light of the Balkan model of the world is made by Tsivyan (Tsivyan 1999:91-103). The author sees dativus ethicus as a result of the fusion of the genitive and the dative case and the capacity of the pronominal clitics to express both a direction of an action and possession. Therefore, dativus ethicus in the Balkan languages is bound up 
with the category of possessivity. However, this is a possession of a special kind - the speaker is situated inside the statement declaring his presence in the text. Tsivyan calls this act of appropriation "a linguistic gesture in a self-direction". Her research is based exclusively on folklore texts. The author underlines that in the folklore, dativus ethicus does not have so much an emotional value, but it emphasizes the presence of the speaker in the world of the text by presenting it in the context of the verbal category of evidentiality.

\section{Dativus Ethicus in the Modern Balkan Languages}

Besides the Balkan folklore, dativus ethicus is also widely spread in the modern languages of the Balkan Schprachbund. However, in contemporary speech, in contrast to folklore texts, it is a means of the speaker to express his subjective evaluation of the situation. In Bulgarian, Romanian and Albanian, the forms of $1^{\text {st }}$ person singular and $1^{\text {st }}$ person plural are mostly used, while the $2^{\text {nd }}$ person plural is rarely used in Bulgarian and Romanian. A frequent usage in modern Bulgarian has the short form of the reflexive pronoun. In Greek, the ethic dative has a restricted usage as compared with the other Balkan languages, which is compensated by the frequent usage of the possessive pronominal clitics, as shown by Tsivyan (Tsivyan 1999:96-98).

\section{1. $1^{\text {st }}$ Person of Dativus Ethicus}

The 1st person expresses most distinctly "the intervention" of the speaker in the utterance by giving emotional nuances of the speech and by expressing the subjective evaluation of the speaker. In all the Balkan languages it is made by the 1st person singular, in Albanian in addition the $1^{\text {st }}$ person plural is used by which the speaker presents himself as a representative of a multitude.

(1a) Bulg. Какъв си ми хубав!

What are me:DE beautiful

'You are so beautiful to me!'

(1b) Bulg. Марче, вземи се в ръце, бе момиче. Я какво си ми младо и слабичко, а аз какво да кажа с моите 85 килограма.

Marche take yourself in hands part. girl part. what are me:DE young and thin and I what to say with my 85 kilograms

'Marche, take it easy, girl. Look how young and thin you are, what should I say with my 85 kilos.' 


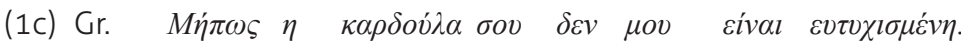
Maybe the heart your not me:DE is pleased 'Maybe your heart is not pleased?'

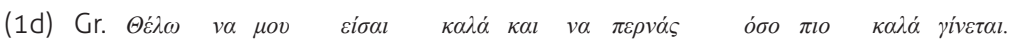
Want-I to me:DE be-you well and to spend-you as more well happens 'I want you to be well and to spend your time as well as possible.'

(1e) Rom. Aici m-ai fost? (I. Creangă, GLR: 150) Here me:DE have-you been

'So, there you are.'

(1f) Alb. Lulushen, të ma keni kujdes. (D. Agolli) Lulusha:Acc to me:DE take care 'Take care of Lulusha.';

(1g) Alb. O bo bo, kush më qenka në këtë forum, moreee.. Well, well who me:DE is in this forum part.

'Well, well, look who was in this forum.'

In the examples above the speaker expresses his positive attitude towards the object of the speech by using dativus ethicus. In such cases it can be easily transformed in a possessive pronoun - my, my dear. Take care of Lulusha. > Take care of my (dear) Lulusha. This is a typical way of expression of a positive evaluation by appropriation or by affiliation, a means of the speaker to admit the object in his own world.

Dativus ethicus can also express a negative attitude - neglect, irony or mockery:

(2а) Bulg. Ооо, тя щзе мисе труди...

Oh she will me:DE work

'So, she will work.'

(2b) Bulg. Какво си ми се разииврила!

What me:DE are crying

'What are you crying!'

(2c) Rom. Ǎsta îmi eşti tu!

This me:DE are you

'So, you are that kind of man!'

(2d) Alb. Na nxjerrka ai libra për bujqit! (D. Agoll)

Us:DE takes out he books for the farmers

'So, he quotes books for farmers!'

In $(2 a, b, c, d)$ a false gesture of appropriation takes place in order to express the speaker's negative attitude towards the situation or the object spoken. This is a transpositive usage of dativus ethicus which transforms the speaker's evaluation from positive into negative thus increasing the expressiveness of the utterance. 
In Bulgarian and Albanian, where the verb category of evidentiality is grammaticalized, often a parallel usage of dativus ethicus and admirative verb forms is encountered. The admirative in Bulgarian and Albanian is defined as a sudden ascertainment of facts which is unexpected and surprising for the speaker and provokes a particular emotional condition (Gerdzhikov 1984:101). The expressiveness of the verbs in admirative provides a possibility for the speaker to give voice to his subjective evaluation of the situation ascertained. This is a secondary and contextually dependent function of the admirative, but quite frequent in both languages (see Tarpomanova 2010). Adding a pronoun in ethic dative the speaker gives emphasis on the subjectivity of his own appraisal.

(3а) Bulg. И това ми било мъж!

And this me:DE is:adm. man

'So, that would be a real man!'

(3b) Bulg. Изтъпанчил ми се на онзи големия баир в Минск и гради първото иглу за сезона.

Stands:adm. me:DE on that big hill in Minsk and builds the first igloo for the seazon

'He stands on the big hill in Minsk and builds the first igloo for the season.'

(3c) Alb. E, domethënë Sherif Abeceja na qenka edhe besimtar! (D. Agolli) Eh so Sherif Abeceja us:DE is:adm. also believer

'So, Sherif Abeceja is also a believer!'

In $(3 a, b, c)$ the pronominal and the verbal form mutually intensify their meanings, expressing the emotional attitude of the speaker and his pragmatic evaluation - positive or negative, of the object of the utterance.

\section{2. $2^{\text {nd }}$ Person of Dativus Ethicus}

The $2^{\text {nd }}$ person of dativus ethicus aims to integrate the collocutor into the situation described by the utterance, as if he was an eyewitness of the events. The opposition mine/not mine takes place between the $1^{\text {st }}$ and the $2^{\text {nd }}$ person, on one hand, and the $3^{\text {rd }}$ person, on the other. A translocation occurs in the internal correlation me/you - the speaker gives the possibility of the collocutor to express the emotional attitude of the utterance. According to Bokshi, the pronominal clitics in $2^{\text {nd }}$ person should not be considered as dativus ethicus, being a neutral form for expressing the person, or an "all-personal" form. He claims that the emotional value of ethic dative can only be expressed by the $1^{\text {st }}$ person, because the speaker is a concrete person, while the neutral you may be either me, you or him/her (Bokshi 2004:79-81). Bokshi's opinion is not sustained here and a distinction is made between the $2^{\text {nd }}$ person of the personal pronouns expressing impersonality (all-personality, according to Bokshi) and the $2^{\text {nd }}$ person of the 
pronominal clitics in dativus ethicus. The differences between the two meanings can be observed in the examples below. In (4a) the neutral function of the $2^{\text {nd }}$ person pronoun is notable. The elimination of the pronoun would damage the sentence structure and meaning. In (4b) the pronoun expresses the speaker's surprise and admiration and if it's removed the speaker' attitude will be lost, but the sentence grammaticality and meaning will be preserved.

(4a) Alb. $\mathrm{Ti} i$ bën mirë, ai ta kthen metëkeq. You him do good he you returns bad 'You do him good, he returns you evil.'

(4b) Alb. Pa t'u bë ai fiku sa njështëpi. And you:DE became this fig-tree like a house 'And the fig-tree became as big as a house.'

\subsection{Parallel Usage of $1^{\text {st }}$ and $2^{\text {nd }}$ Person}

In Bulgarian, Romanian and Albanian a parallel usage of the $1^{\text {st }}$ and $2^{\text {nd }}$ person pronouns in dativus ethicus is possible. In Bulgarian this usage is restricted - the two pronouns can be in enclitic position only after demonstrative (5a), interrogative ( $5 b$ ) and indefinite $(5 c)$ pronouns, the latter expressing pragmatic evaluation, positive or negative, intensified by the dative pronominal clitics.

(5а) Bulg. Надолу очи да метнеш, кипнала оная ми ти земя, напращели ония младоии, надули се ония ми ти пъпки по фиданките... (Chudomir) Down eyes to throw-you boiled that me:DE you:DE land burst those young people grew those me:DE you:DE buds on the trees 'If you look down, you will see this land boiling, these young people bursting, these buds growing.'

(5b) Bulg. Каква Европа, какви ми ти там хелзинкски комитети и други подобни плутократски организации.

What Europe what me:DE you:DE there Helsinki Comittees and other similar plutocratic organizations

'What Europe, what Helsinki Committees and similar plutocratic organizations.'

(5c) Bulg. Тъкмо се настаних удобно, като се накачиха във влака едни ми ти иигани, пардон, роми.

Just sat-I down comfortably when got on the trains some me:DE you:DE gypsies pardon roma

'I just sat down comfortably when some gypsies, ops... Roma people, got on the train.' 
In Romanian and Albanian the parallel usage of the $1^{\text {st }}$ and the $2^{\text {nd }}$ person of the pronouns in dativus ethicus is not submitted to usage restrictions as in Bulgarian.

(5d) Rom. Mi-au lunecat ciubotele şi am căzut în Ozana, cât mi ți-i băietul! To me slipped the boots and fell-I on Ozana what me:DE you:DE man 'My boots slipped and I fell on Ozana, what a man!'

(5e) Rom. Ce credeți că mi ți văzu? (GLR:150) What think-you that me:DE you:DE saw-I 'And what do you think I saw?'

(5f) Alb. E të na u bë baltë e madhe, e të na u bënë, or të keqen këmbët gjak. (Bokshi 2004:80) And you:DE us:DE became mud big and you:DE us:DE became badly blood 'And everything became mud and our feet became all in blood.'

As shown in the exemples $(5 a, b, c, d, e, f)$, the parallel usage of the $1^{\text {st }}$ and the $2^{\text {nd }}$ person of the pronouns acts as intensifier of the semantic property of the word modified which can be explicit, as in (5f) "really big mud", or implicit, as in (5a) "really (beautiful) land", in (5c) "really (awful) gypsies", and in (5d) "what a (handsome) man". Besides, the combination of the pronouns can modify the whole meaning of the utterance by increasing its emotional value, as in (5e) "And what do you think I saw? (It's really incredible!)"

\subsection{Combination of Dativus Ethicus with Deictic Particles}

For Bulgarian Nitsolova mentions the usage of pronouns in dativus ethicus with deictic particles with predicative function (Nitsolova 1986:57). The case in point is the combination of the $2^{\text {nd }}$ person of the pronominal clitics with the particles here, there. This usage is characteristic also of Greek and Romanian and may be considered as an abstract gesture of giving on the part of the speaker. The meaning of the whole construction is a negative issue of some situation that is previewed from the speaker.

(6а) Bulg.На ти сега социализъм, на ти митинг!

There you:DE now socialism there you:DE demonstration

'There you have your socialism, there you have your demonstration!'

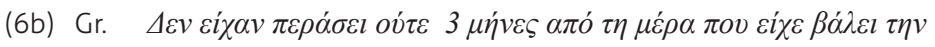

Not had passed even 3 months from the day that had-he put the

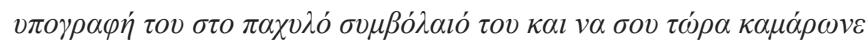
signature his on the pompous council and there you:DE now boasted- he

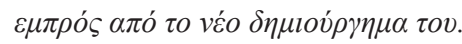

in front of the new creation his

'Less than 3 months have passed since he put his signature under the pompous council and there you go, he's boasting with his creation.' 
(6c) Rom. lată-ți gloria de veacuri!

There you:DE glory for centuries

'There you have your century-old glory!'

\subsection{The Reflexive Pronoun in Dativus Ethicus}

In Bulgarian a frequent usage in dativus ethicus has the dative reflexive pronoun si, which is a Slavic characteristic in this language. Among the other Balkan languages only in Romanian a dative reflexive pronoun exists, but its usage in dativus ethicus is marginal and it is encountered only in the folklore (Câmpeanu 1997):

(7) Rom. Toțide Corbea că mi vorbeaşi din gură mi-şi zicea. All from Corbea that to me spoke and from mouth to me refl.pron.:DE told 'All the people from Corbea spoke to me and with their mouths told me.'

In Bulgarian the reflexive pronoun in dativus ethicus means that the action is performed for pleasure or for whim or expresses intimacy (Nitsolova 1986:68):

(8a)Bulg. Гледам си в тавана, по който мухите пълзят, и хоп, ето ти тема: „Защо мухите не падат, когато са с главата надолу?"

Look-I refl.pron.:DE at the ceiling on which flies creep and up there is theme why the flies don't fall when are upside-down

'I was looking at the ceiling, where the flies were creeping, and suddenly a theme submerged: "Why the flies don't fall down being upside-down?"

(8b) Bulg. Kучетата си лаят, керванът си върви.

The dogs refl.pron.:DE bark the caravan refl.pron.:DE goes

'The dogs bark but the caravan goes on."

\section{Conclusion}

Dativus ethicus is a common feature of the Balkan languages, an IndoEuropean inheritance preserved and developed in the modern languages, which contributes to the expressiveness of speech and is one of the means to articulate a pragmatic evaluation of a given situation, event or the object of the utterance. Its usage, as shown in the examples in this paper, is characteristic of colloquial speech, making it bright and vivid. 


\section{References}

Asenova, P. 2002. Balkan Linguistics. Sofia. (In Bulgarian)

Bokshi, B. 2004. On the Personal Pronouns of Albanian. Prishtinë. (In Albanian)

Câmpeanu, E. 1997. Stylistics of the Romanian Language. Cluj-Napoca. (In Romanian)

Demiraj, S. 2004. Balkan Linguistics. Tirana. (In Albanian)

DuFeu, V. 1998. The Dativus Ethicus (DE) in the Slavonic Languages. - XII MKS KRAKÓW 1998. Retrieved from: http://www.arts.gla.ac.uk/Slavonic/VDuFeu.htm

Feuillet, J. 2012. Linguistique comparée des langues balkaniques. Paris.

Fischer, K. 1997. German-English Verb Valency: A Contrastive Analysys. Tübingen.

Gerdzhikov, G. 1984. Renarration of the verb action in Bulgarian. Sofia. (In Bulgarian)

GLR: Grammar of the Romanian Language, vol. 1. Bucarest, 1966. (In Romanian)

Nitsolova, R. 1986. Bulgarian Pronouns. Sofia. (In Bulgarian)

Reiter, N. 1994. Grundzüge der Balkanologie. Ein Schritt in die Eurolinguistik. Berlin - Wiesbadden.

Sandfeld, K. 1930. Linguistique balkanique. Problèmes et résultats. Paris.

Schwyzer, E. 1950. Griechische Grammatik. München. 
Major Trends in Theoretical and Applied Linguistics

Steinke, C. \& A. Vraciu. 1999. Introduction in Balkan Linguistics. Iasi. (In Romanian)

Tarpomanova, E. 2010. The Admirative in Bulgarian and Albanian. In: Balgarski ezik, 57 (2010), 1: 45-66. (In Bulgarian)

Tsivyan, T.V. 1999. Motion and Road in the Balkan Model of the World. Moscow. (In Russian) 